症例報告 一最優秀臨床ポスター賞受賞一

\title{
骨格性下顎前突症を伴う広沉型重度慢性歯周炎に 包括的治療を行った一症例
}

白方良典 ${ }^{* 1}$, 山本芳丈*2, 野口和行*1,3

*1 鹿児島大学大学院医歯学総合研究科歯周病学分野

*2鹿児島大学大学院医歯学総合研究科歯科矯正学分野

*3鹿児島大学大学院医歯学総合研究科口腔先端科学教育研究センター

Comprehensive treatment of a severe chronic periodontitis patient with skeletal Class $\amalg$ : a case report

\author{
Yoshinori Shirakata*1, Yoshitake Yamamoto*2 and Kazuyuki Noguchi*1 \\ ${ }^{* 1}$ Department of Periodontology, Kagoshima University Graduate School of Medical and Dental Sciences \\ *2Department of Orthodontics, Kagoshima University Graduate School of Medical and Dental Sciences \\ ${ }^{*}$ Education and Research Center for Advanced Oral Sciences
}

\begin{abstract}
Tooth displacement occurring at a high prevalence in patients with severe periodontitis is defined as pathologic tooth migration (PTM). For these patients, the malposition of the teeth not only creates unfavorable conditions for maintaining good oral hygiene, but also causes occlusal discrepancy and further traumatic occlusion. Consequently, it easily promotes progression/recurrence of periodontal disease. Herein, we present the case of a 49-year-old woman with generalized severe chronic periodontitis exhibiting several PTMs with categorized into skeletal Class $\amalg$. The patient received comprehensive treatment, including periodontal initial therapy, periodontal surgery (bone grafting), localized orthodontic treatment utilizing a removable bite plate and orthodontic anchor screws, and restorative/prosthodontic treatment. Through this interdisciplinary approach, a favorable periodontal condition, consecutive dentition, and proper anterior guidance were efficiently restored in a relatively atraumatic manner. The periodontal health and stable occlusion were well maintained until at least 3 years later in the patient on supportive periodontal therapy. The findings in this case suggest that an interdisciplinary approach, including orthodontic treatment, for controlling both inflammation and occlusal force is essential for achieving successful results of periodontal treatment in patients with severe periodontitis and PTM.
\end{abstract}

Nihon Shishubyo Gakkai Kaishi (J Jpn Soc Periodontol) 56(4) : 442-450, 2014.

Key words : chronic periodontitis, pathologic tooth migration (PTM), interdisciplinary approach

連絡先：白方良典

T 890-8544 鹿児島県鹿児島市桜ケ丘 8-35-1

鹿児島大学大学院医歯学総合研究科歯周病学分野

Yoshinori Shirakata

Department of Periodontology, Kagoshima University Graduate School of Medical and Dental Sciences

8-35-1 Sakuragaoka, Kagoshima 890-8544, Japan

E-mail : syoshi@dent.kagoshima-u.ac.jp 
要旨: 重度歯周炎患者においては病的で著しい歯の移動 (Pathologic tooth migration: PTM) による歯列不正が 認められることが少なくない。こうした患者において歯列不正が存在するとブラッシングが困難であるばかり か, さらに咬合の不調和や外傷性咬合が発現することにより歯周炎の増悪や再発が起き易いと考えられる。今回, 骨格性下顎前突症と多くの PTM を伴った広汎型重度慢性歯周炎を有する 49 歳女性患者に, 歯周基本治療, 骨移 植術を含む歯周外科治療，可撤式バイトプレートと矯正用アンカースクリューを利用した部分的矯正治療，およ び修復・補綴治療を包括的に行った。この結果，低侵襲かつ効率的に歯周組織の環境改善と歯列の連続性，適切 なアンテリアガイダンスが獲得された。現在, supportive periodontal therapyに入り 3 年経過したが, 良好に歯 周組織と咬合の安定が維持されている。本症例から PTM を有する重度慢性歯周炎患者に扔いては, 矯正治療を 含む包括的治療により PTM を解消し，炎症と力のコントロールを行うことが歯周治療を成功させるために極め て有効であることが示された。

日本歯周病学会会誌（日歯周誌）56(4)：442-450, 2014

キーワード：慢性歯周炎, 病的歯の移動（pathologic tooth migration：PTM）, 包括的治療

\section{諸言}

歯周病は口腔内のプラーク細菌が原因となり発症す る炎症性疾患である。未処置のまま病変が進行すると 著しく歯周支持組織が破壊され, 不可逆的な歯の動摇 や歯の哀失をもたらす。こうした歯の欠損部位が長期 的に放置されることで, さらなる残存歯の移動やコン タクトの不整等が生じ, プラークの蓄積が助長され る。実際, 歯周炎罹患患者においては病的な歯の移動 (Pathologic tooth migration: PTM) が，その 30\%〜 $55.8 \%$ で認められると報告されている ${ }^{1-3)}$ 。こうした プラークコントロールが行い難い状況で歯肉の炎症や 歯周ポケットの形成が慢性化すると, 歯周支持組織が 弱体化し残存歯に加わる機能圧の変化が生じ, 歯周組 織の適応能力を超えた咬合力やブラキシズム・早期接 触などに起因して外傷性咬合として作用すると二次性 咬合性外傷を認めるようになる4)。その結果, 歯槽骨 吸収がさらに進行し歯の動摇が増加の一途を辿る。こ うした負のスパイラルを断ち切り, 長期的に歯周組織 の安定拉よび歯周炎の再発防止を達成するには，プ ラークやそのリテンションファクターの除去を主体と する炎症のコントロールのみならず，咬合の安定化と 咬合力の分散といった力のコントロールが必須と考え られる。すなわち, 歯周病患者において PTM が残存 するとブラッシングが困難であるばかりか, さらなる 咬合の不調和や外傷性咬合の発現により歯周炎の増悪 や再発が起き易いと考えられる。こうしたことから， 特に PTM を有する歯周病患者に扔いては長期的予後 を考慮すると PTM を解消することが極めて重要であ ると考えられる。今回, 骨格性下顎前突症と多数歯の PTM を伴う広沉型重度慢性歯周炎患者に対して歯周 基本治療, 歯周外科治療, 可撤式バイトプレートや矯
正用アンカースクリューを用いた部分的矯正治療およ び修復・補緅治療を包括的に行い, 炎症と咬合を管理 し易い口腔内環境へ整備することで, 良好な歯周組織 と咬合の安定が維持されている症例について報告す る。

\section{症例}

患者：49歳.女性

初診日：2007 年 11 月 19 日

主訴：下顎前歯部の動摇とブラッシング時の出血

\section{1. 全身既往歴}

気管支喘息 (小学生時) およびアトピー性皮虐炎(現 在も時々生じる)があるが, その他には, 特記すべき全 身既往はない。

\section{2. 口腔既往歴}

下顎前突の状態は小さい頃からで変化はないが, 10 年ぐらい前から歯の動摇や部分的な歯の位置異常があ ることを自覚するようになった。歯肉腫脹 (特に臼歯 部)やブラッシング時の出血も同時期より気づいてい たが, 痛みがないため放置していたという。これまで カリエス治療のみを近医にて行っていたが, 2007 年の 夏頃より下顎左側側切歯 (32) の動摇が大きくなり, ま た咬合痛が生じるようになった。近医を受診したが, 抜歯と診断されたためセカンドオピニオンを求め鹿児 島大学医学部歯学部附属病院に来院した。

\section{3. 家族歴}

両親は老年時に義歯を装着しており, 姉は矯正治療 の既往があるが長期的に歯科治療を必要としていた者 はいない。 


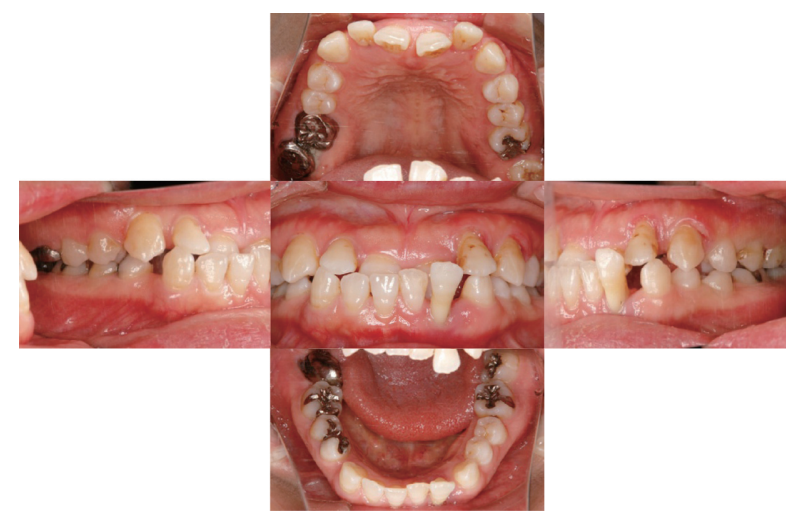

図 1 初診時口腔内写真（2007 年 11 月）

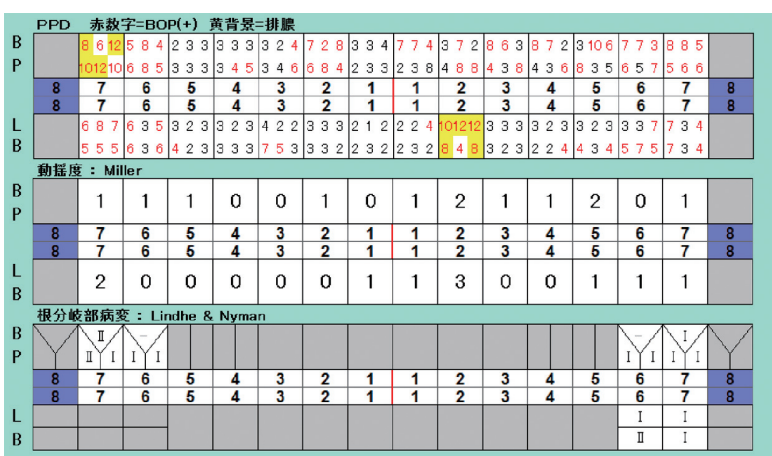

図 2 初診時歯周組織検查所見（2007 年 11 月）

\section{4. 生活習慣および習癖}

喫煙歴掞よび飲酒習慣はないが，噛みしめをしてい ることがある。

\section{5. 現症}

1)全身所見

身長 $160 \mathrm{~cm}$ ，体重 $65 \mathrm{Kg}$ で体格指数（BMI）は 25.4 でやや肥満傾向であった。

2) 口腔内所見

\section{(1) 肉眼所見}

初診時の口腔内写真を図 1 に示す。現在歯数は 28 歯で下顎の突出のほか, 多数歯に PTM (捻転 11，21, 27 , 挺出 11，21，17，27，32，44，煩側転位 17，27, 舌側転移 47 , 唇側傾斜 $13,12 ， 22 ， 23$, 舌側傾斜 37 , 46)が認められた。上顎口蓋側の歯肉は全般的に厚く 肥厚した上，全顎的に歯間乳頭部歯肉と辺縁歯肉に発 赤・腫脹が強く認められた。また $17,32 に は$ に排膿が認 められた。口腔衛生状態は不良で O'leary のプラーク コントロールレコード（PCR）は68\%であった。

(2) 歯周精密検査

プロービングデプス $(\mathrm{PD})$ の平均は $4.6 \mathrm{~mm}, \mathrm{PD} \geqq 4$ $\mathrm{mm}$ の部位は $51.2 \%$ 占め，プロービング時の出血

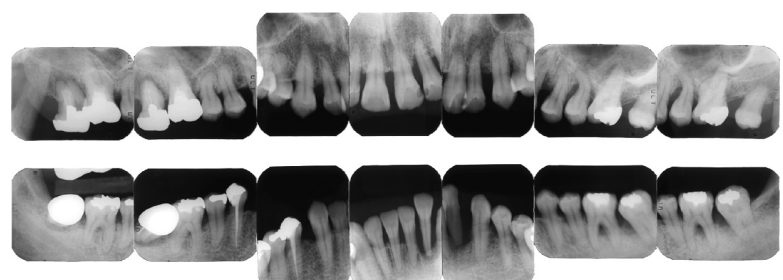

図３初診時デンタルエックス線写真（2007 年 11 月）

(BOP 陽性) 部位は $47.6 \%$ あった。過半数の歯に軽 度〜重度の動摇が認められ, 特に 32 は動摇度 3(Miller の分類）であった。大臼歯部 $(17,16,26,27,36,37)$ には根分岐部病変（I～II 度：Lindhe\& Nyman）が散 在していた（図 2)。

(3)エックス線所見

全顎的に歯根の $1 / 2$ に及ぶ水平性骨吸収が認められ ると共に $16 ， 14 ， 13 ， 12 ， 22 ， 23 ， 24 ， 25 ， 35 ， 37$ に 垂直性骨吸収を認めた。32については根尖部に及ぶ 骨吸収像が認められた。また, 17 の根尖部および 36 の根分岐部には骨透過像が認められ，44の遠心にはイ ンレー修復後の二次カリエスが認められた（図 3)。

\section{6. 診断}

1) 歯周病診断

広沉型重度慢性歯周炎，二次性咬合性外傷

2) 矯正診断

前歯部反対咬合を伴う骨格性下顎前突症

(1) 白歯関係 左側山級 右側山級

(2)顔面形態 左右対称 concave type

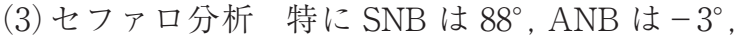
IMPA は $104^{\circ}$, Go-Pog は $83 \mathrm{~mm}$ と標準值より 1SD 以上大きく, Overjetは $-4 \mathrm{~mm}$, Overbite は $5 \mathrm{~mm}$ であった。

\section{7. 病因}

1)全身的因子：特記すべき事項なし

2) 局所因子：プラーク, 歯列不正, 外傷性咬合, クレ ンチング

\section{8. 治療計画}

1) 歯周基本治療により炎症性因子の除去と咬合性外傷 のコントロールを可及的に図る。

2)再評価検査後, 歯槽骨形態の修正と歯周組織の再生 を目的とした歯周外科治療を検討する。

3)外傷性咬合の発現リスクを減じ，咬合の緊密化とプ ラークコントロールを行い易い口腔内環境を整備する ため，矯正治療により被蓋の改善と歯列不正の是正を 行う。 


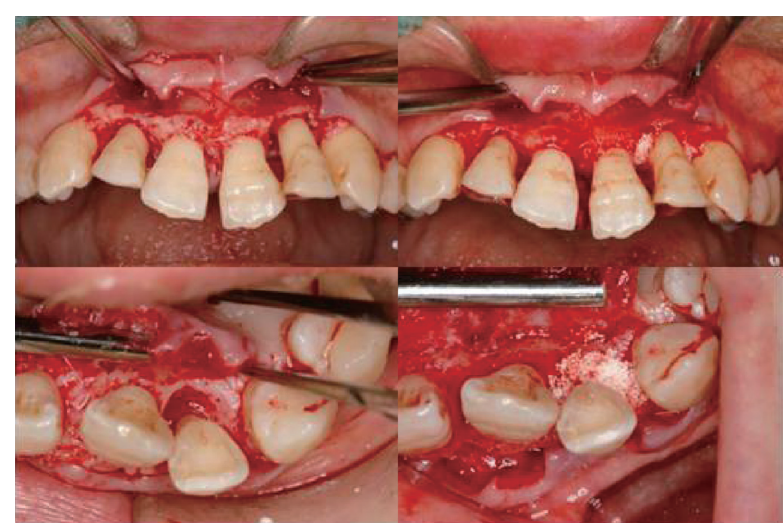

図 4 12 22 歯肉剝離掻爬術 骨整形, 人工骨移植

4)再評価検査後, 咬合の安定化を目的とした口腔機能 回復治療として最小限の侵襲で審美性と機能性を備え た補綴・修復処置を行う。

5) 最終評価後, 定期的な Supportive periodontal therapy (SPT) に移行し, 長期的な口腔内環境の維持・管 理に努める。

\section{9. 治療経過}

1) 歯周基本治療（2007 年 11 月～2008 年 3 月）

口腔衛生指導（バス法および歯間清掃用具の使用） と共に, 主要なプラーク感染源と考えられる保存不可 能歯 (32) および不働歯 $(17,27,47)$ の抜歯を早期に行っ た。32 抜歯部位については人工歯を $31 〜 33$ 部におい て接着性レジンセメントで固定した。歯肉縁上のプ ラークコントロールが確立した後 $(\mathrm{PCR} \leqq 20 \%$ で安 定), スケーリング・ルートプレーニング (SRP) を行っ た。また，早期接触や側方運動にて咬頭干渉を認める 歯 $(12 ， 11 ， 21 ， 22 ， 32 ， 33 ， 42 ， 43)$ につては咬合 調整を併せて行い，可及的に外傷性因子を除去した。

2)再評価（2008 年 4 月）

歯周基本治療後の再評価で PD の平均は $2.9 \mathrm{~mm}$, $\mathrm{PD} \geqq 4 \mathrm{~mm}$ の部位は $20.1 \%$, BOP 陽性部位は $8.3 \%$ と 改善を認めた。しかしながら，上顎前歯部，上下顎両 側臼歯部には $4 \mathrm{~mm}$ 以上の歯周ポケットが残存し, 骨 内欠損と骨形態の不整が認められたため歯周外科治療 を行うこととした。

3) 歯周外科治療（2008 年 5 月～2008 年 9 月）

(1) 上顎前歯部 $(12 \sim 22)$

歯肉剥離掻爬術を施行し，12２2 部の唇側根間中隔 部の歯槽骨は棚状を呈していたが顎堤は薄かったため 可及的に骨整形を行った。なお， 12 の近心，遠心側に は浅い 3 壁性骨内欠損が認められデブライドメントを 確実に行った。また 22 の近心, 口盍側, 遠心にかけて 深いすり鉢型の骨欠損を認めた。術野において採取で

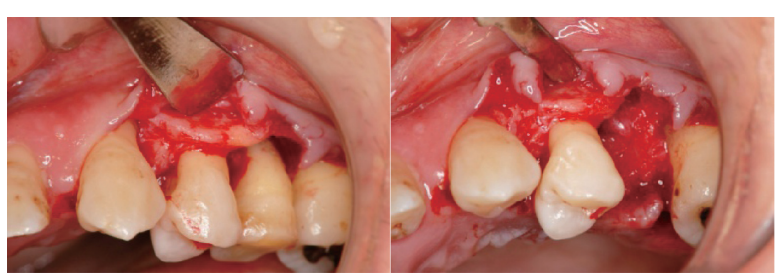

図 $523 \sim 26$ 歯肉剝離掻爬術 骨整形, 自家骨移植

きる自家骨は僅かであったため, コラーゲン使用人工

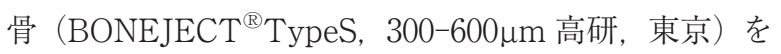
22 周囲の骨内欠損へ充填した（図 4)。

(2) 上顎左側前歯〜 臼歯部 $(23 \sim 26)$

26 遠心煩側および口蓋側に $5 \mathrm{~mm}$ の歯周ポケット を認め, 同部に厚い歯肉が残存したため distal wedge を加え, 歯肉剥離掻爬術を行った。25の煩側骨壁は残 存していたが, 近心から遠心にかけてすり鉢型の骨吸 収が存在し，口蓋根はその $1 / 2$ まで水平性骨吸収が認 められた。歯根長も極めて短いことから予後不良と判 断し抜歯を行った。23 遠心には口蓋および遠心側の 骨壁が残存する 2 壁性骨内欠損を認めたため, 25 の抜 歯窩壁の骨鋭縁から採取した自家骨骨片を用いて自家 骨移植を行った（図 5)。なお, 25 の欠損部については 歯肉弁の復位・閉鎖を行った後, 接着性レジンセメン トを用いて人工歯を固定した。

（3）下顎左側臼歯部（35～37）

37 の動摇度は 1 度で㚘側と舌側の根分岐部病変は I 度であったが, 近心の骨吸収は根尖部にまで一部及 んでいた。また舌側傾斜があり歯根離解度も小さいた め, プラークコントロールが困難で炎症の波及も早い と判断し歯周外科処置中に抜歯を行った。36の煩側 にはすり鉢型の骨欠損と II 度の根分岐部病変を認めた ため, 37 の抜歯窩壁の骨鋭縁および臼後結節部から採 取した自家骨骨片を用いて 36 の骨内欠損へ自家骨移 植を行った。

\section{(4) 上顎右側臼歯部 $(14 \sim 16)$}

16 遠心煩側およびロ蓋側に $5 \mathrm{~mm}$ の歯周ポケット を認め, 同部に厚い歯肉が残存したため distal wedge を加え歯肉剥離掻爬術を行った。16の口蓋根はその 1/3 まで骨吸収を認めたが, 水平的であったため保存 可能と判断し切除療法で対応した。13,14の煩側に骨 隆起を認めたため除去し, 15,16 間の煩側の棚状歯槽 骨に対して骨整形を行った。

（5）下顎右側臼歯部 (44４6)

上顎右側臼歯部同様，46に歯周ポケットが 4〜 5 $\mathrm{mm}$ 残存し水平性骨吸収を認めたため歯肉剥離掻爬術 を行い，44，45，46 間の㚘側の棚状歯槽骨に対して骨 整形を施した。 


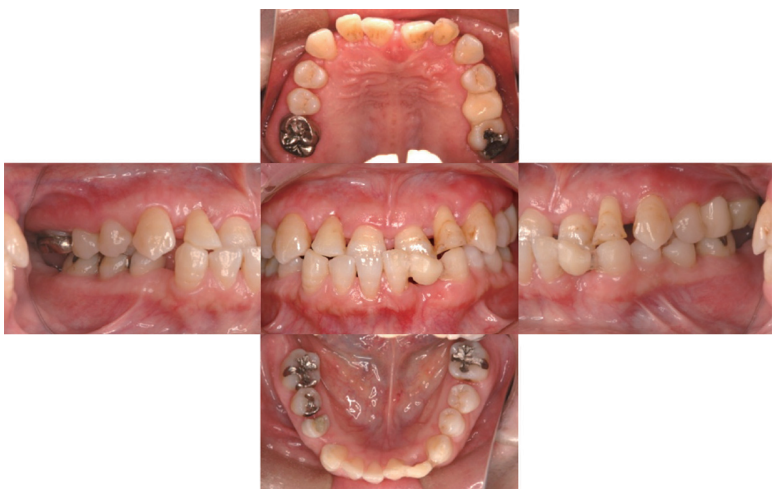

図 6 歯周外科治療後再評価時の口腔内写真（2008 年 11 月)

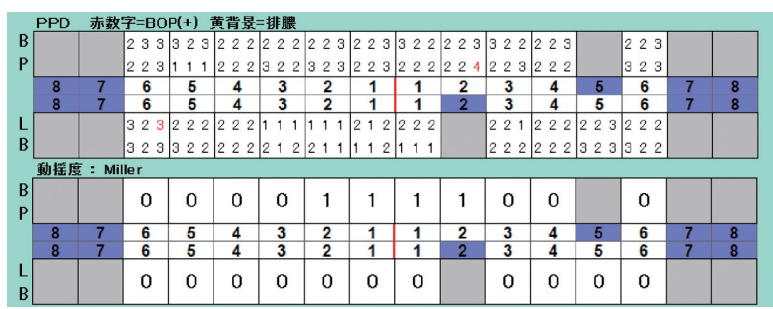

図 7 歯周外科治療後再評価時の歯周組織検査所見（2008 年 11 月）

外科処置後に歯の動摇や早期接触, 咬頭干涉が生じ た場合は必要に応じて咬合調整を行い，安静を図っ た。術後に歯間鼓形空隙の拡大が生じた部位の歯間部 清掃の変化については口腔衛生指導を再度徹底した。

4) 再評価 (2008 年 11 月)

歯周外科処置後の再評価では, PDの平均は 2.1 $\mathrm{mm}, \mathrm{PD} \geqq 4 \mathrm{~mm}$ の部位は $0.8 \%$ で根分岐部病変は触 知されず，BOP 陽性部位は $1.6 \%$ と改善を認めた（図 6〜困 8)。44 遠心部の縁下の二次カリエスについて も，歯肉縁上で対処できるようになり，インレー除去 後，アンレーを製作，装着した。なお，36 近心にもカ リエスを認めたためインレーを再製後, 装着を行った。 PCR は 15\%前後で安定し歯肉の炎症が十分にコント ロールされていることを確認後, 部分的矯正治療へ移 行した。

5) 矯正治療（2009 年 6 月～2011 年 1 月）（20 力月）

可撤式バイトプレートを用いて切端咬合位まで可及 的に咬合の挙上を行い, (1)上顎前歯の被蓋の改善（4 カ月間) (2)矯正用アンカースクリュー $(\phi 1.6 \mathrm{~mm}, 8$ $\mathrm{mm}, 34,35$ 間 1 本，45，46 間 1 本）を用いて下顎前 歯部 (32 相当部の人工歯を削合しながら) の空隙閉鎖 (9〜10 カ月間) (3)上顎の空隙閉鎖および上下顎咬合の 緊密化 (7 カ月) を行った（図 9)。矯正治療後のセファ

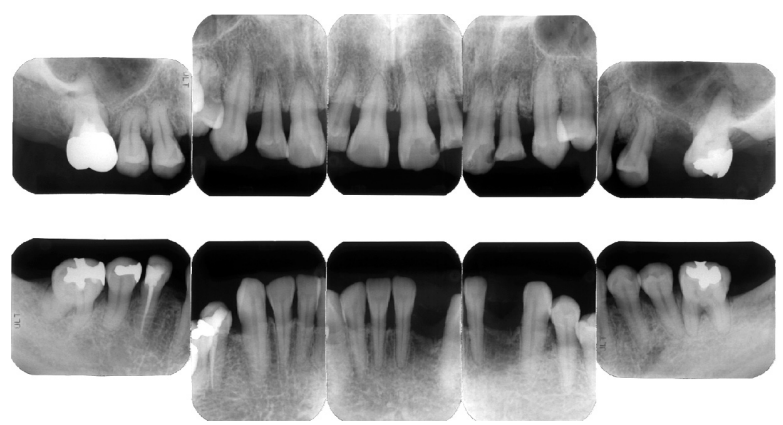

図 8 歯周外科治療後再評価時のデンタルエックス線写真 (2008 年 11 月)

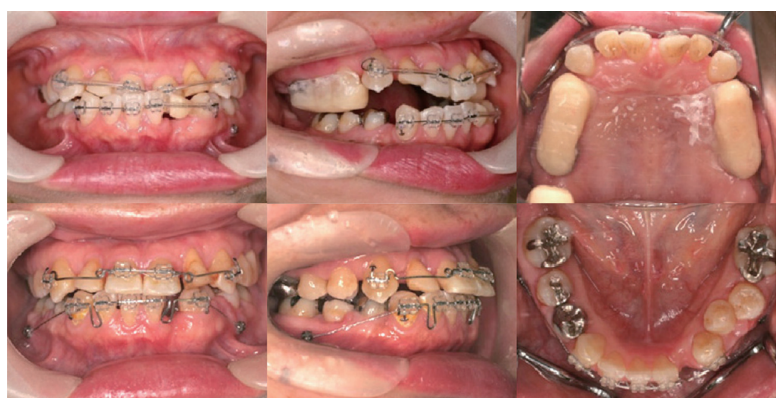

図 9 部分的矯正治療中の口腔内写真

(上段：可緅式バイトプレートを用いてバイトアップしな がら被蓋の改善, 下段：矯正用アンカースクリューを用い た下顎前歯のスペース閉鎖)

ロ分析において SNB と ANBに変化は認められな かったが, IMPAは $88^{\circ}$ に, overjetは $4 \mathrm{~mm}$, overbite は $3.5 \mathrm{~mm}$ へ改善が認められた。矯正治療期間中は歯 の移動に伴い生ずる早期接触および咬頭干渉部位の咬 合調整を適宜行った。また，これまでのプラークコン トロールに併せて歯冠部の矯正装置周囲のブラッシン グについても注意するよう指導を継続した。

6)再評価 (2011 年 2 月)

$\mathrm{PD}$ の平均は $2.1 \mathrm{~mm}, \mathrm{PD} \geqq 4 \mathrm{~mm}$ の部位は $1.5 \%$, BOP 陽性部位は $2.3 \%$ でった。歯周組織について炎 症所見は認められなかったが, ブラケット周囲の歯冠 部の脱灰, 䠘蝕, 着色が多く認められたため $14,15,33$ のコンポジットレジン修復および研磨, 着色除去を 行った。

7) 口腔機能回復治療（2011 年 2 月～2011 年 5 月）

最終補緅処置として, 25 相当部の人工歯を除去した のち，24 および 26 を支台歯とした接着性ブリッジを 作製し装着した。なおマージンの不整で二次カリエス が認められた 16 についても FMC を再作製し，装着 を行った。

8)最終評価 (2011 年 6 月)

$\mathrm{PD}$ の平均は $2.1 \mathrm{~mm}, \mathrm{PD} \geqq 4 \mathrm{~mm}$ の部位は $0.8 \%$ で 


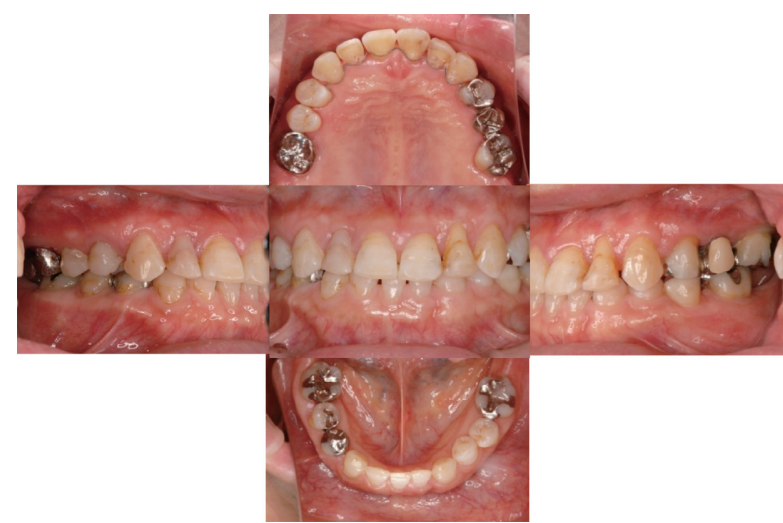

図 $10 \mathrm{SPT}$ 開始 3 年時の口腔内写真 (2014 年 6 月)

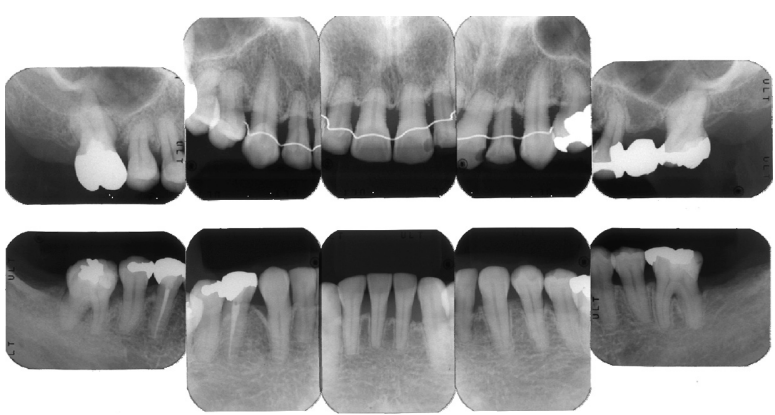

図 11 SPT 開始 3 年時のデンタルエックス線写真 (2014 年 6 月）

あり，BOP 陽性部位は 1.5\%で概ね歯周組織の安定が 認められた。早期接触, 咬頭干渉は認められなかった が, 上顎前歯部 $(12 \sim 22)$ に若干の動摇が残存し, 矯 正治療後の後戻りを防止するため, 同部の口蓋側でボ ンディングワイヤーを用いて保定（固定）を行い, $\mathrm{SPT}$ に入ることとした。なお, パラファンクションの 予防を考慮しナイトガードの作製，装着を行った。

9)SPT（2011 年 6 月〜現在）

SPTへの移行に際し, Lang and Tonetti ${ }^{5)}$ により スクアセスメントにて評価を行った。評価結果は高リ スクであり来院間隔を 3 カ月としていたが初期の段階 で上顎前歯部の固定が外れることがあったため，固定 強化のため昼間は可撤式ソフトリテーナーを補足的に 使用してもらうこととした。また, SPT 移行後 2 年目 に46に二次カリエスを認めインレーの再作製を余儀 なくされた。これらのことから極力, 2 力月以内と来 院間隔を短くしプラークチェック, 咬合の確認, 歯の 後戻りの有無を確認の上, PMTC とフッ化物の塗布 を主体としたSPTを行っている。

$\mathrm{SPT}$ 移行後 3 年の口腔内写真, デンタルエックス線 写真, および検査結果を示す（図 10～図 12)。PPD 平 均 $2.0 \mathrm{~mm}, \mathrm{PD} \geqq 4 \mathrm{~mm}$ の部位は認められず, BoP 陽

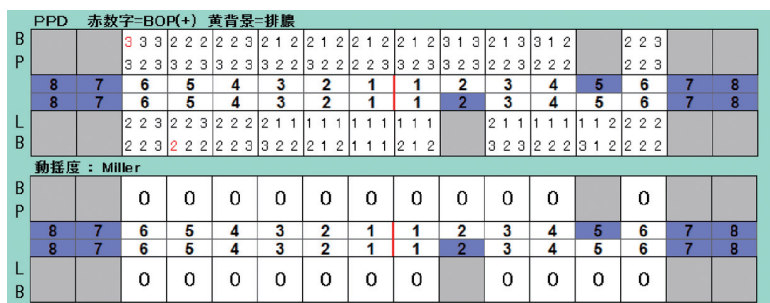

図 $12 \mathrm{SPT}$ 開始 3 年時の歯周組織検査所見 (2014 年 6 月)

性部位は $1.5 \%$ で全顎的に歯周組織の状態は安定して いる。エックス線所見においても歯槽骨頂部の白線の 連続性が全顎でみられ，骨梁の配列も正常な状態と なった。根分岐部の骨透過像もほぼ消失した。なお， 新たな外傷性咬合は生じておらず咬合は安定しており PCR は 10\%前後で良好である。

\section{考察}

本症例は PTM が多数歯に認められ, さらに骨格性 の下顎前突を有する慢性歯周炎患者であったため，歯 周炎の進行抑制，歯周組織と口腔機能の回復には種々 の包括的アプローチが必要と考えられた。まず歯周基 本治療において保存不可能歯と不働歯を早期に抜歯し プラークコントロールを行い易い口腔内環境を創出 し，早期接触(咬頭干渉)を認める歯については咬合調 整を行い可及的に咬合性外傷のコントロールを行っ た。歯周基本治療後の再評価では, 初診時の平均 $\mathrm{PD}$ $=4.6 \mathrm{~mm}, \mathrm{PD} \geqq 4 \mathrm{~mm}$ の部位 $51.2 \%, \mathrm{BOP}(+) 48 \%$ 力 らそれぞれが $2.9 \mathrm{~mm}, 20.1 \%, 8.3 \%$ と改善し歯周 組織の反応性は良好であった。これについては患者自 身のコンプライアンスが良好で PCR の改善が早期に 認められたことと，非契煙者であったことにも起因し ているかもしれない6-8)。

しかし，上顎前歯部および上下顎両側臼歯部に歯周 ポケットが残存し，骨吸収と骨形態の不良を認めたた め歯周外科を行った。歯周外科処置内容を検討するに あたり，歯槽骨の欠損形態 (硬組織) や周囲軟組織の プロファイルが重要であるが，歯根長についても考察 する必要があろう。白色人種に比べてアジア人（韓国 人）の歯根長は短いことが報告されている ${ }^{9)}$ 。本患者 においては全顎的にアジア人の歯根長平均值（上顎： 18.2〜 $24.5 \mathrm{~mm}$, 下顎 : 18.5〜22.5 mm) よりもさら に短かったため (上顎：14〜22 mm, 下顎：15〜21 mm), 歯冠・歯長長比をこれ以上悪化させないため切除療法 ではなく骨整形と再生療法を主体に考えた。上下顎右 側臼歯部では厚い繊維性の歯肉組織の除去と歯肉形態 の修正，浅い骨内欠損および煩側の棚状骨においては 
骨整形で対応した。上顎前歯部，上顎左側臼歯部およ び下顎左側臼歯部には垂直性の骨内欠損（22，23）と 根分岐部病変 (36) が散在し, 再生療法の適応と考えら れた。22 の近心および遠心は1-2 壁性骨欠損が存在 し口蓋側ではすり鉢型の欠損となっていた。近心で久 損幅 $3 \mathrm{~mm}$ ， 欠損深さ $5 \mathrm{~mm}$ ， 久損角度 $25^{\circ}$ ，遠心では それぞれ $3 \mathrm{~mm}, 4 \mathrm{~mm}, 32^{\circ}$ で口蓋側では欠損幅, 深さ 共に $5 \mathrm{~mm}$ であった。近遠心部の欠損幅は狭かったも のの口蓋側は歯根の $1 / 3$ まで骨吸収が進行しており non-contained type の骨欠損と判断し，骨移植術を適 応した8）。現在，種々の骨補填材が使用されており， 骨形成能，骨伝導能，骨誘導能を全て有する自家骨が 骨補填材としては第一選択であるが，術野内から採取 できる自家骨には限度がある。本症例においては上顎 前歯部の顎堤幅は薄く特に骨隆起も認めなかったこ と, また患者が他部位への二次的外科侵襲を求めな かったため患者の希望で人工骨を用いた。23の遠心 は欠損幅 $4 \mathrm{~mm}$, 久損深さ $5 \mathrm{~mm}$, 久損角度 $40^{\circ}$ のやや 広い2 壁性骨欠損であった。25については骨吸収の 進行が強く歯根形態，歯根長から予後不良と判断し抜 歯を余儀なくされたが，術野内である 25 の健全な煩 側骨壁を採取し 23 の遠心部へ自家骨移植が可能と なった。下顎左側臼歯部においては, 術中に位置異常 と歯槽骨吸収の程度加予後不良と判断し, 37 の抜歯 を行った。そして 36 の㚘頁側にはII度の根分岐部病変 が認められ GTR 法の適応と考えられたが，36の㚘側 の骨レベルは高く維持されており，また 37 遠心部か ら十分な自家骨を採取することができたため膜を利用 することなく，根分岐部内へ自家骨片を用いた自家骨 移植術のみを行った。今回, 手術の適応となった骨内 欠損はエナメルマトリックスデリバティブ (EMD) の 適応とも考えられたが，動物製剤であることから患者 の同意が得られず用いなかった。歯周外科後の再評価 において，臨床的パラメーターおよびデンタルエック ス線所見において歯周基本治療後から改善され， $\mathrm{PD}$ の平均は $2.1 \mathrm{~mm}, \mathrm{PD} \geqq 4 \mathrm{~mm}$ の部位は $0.8 \%, \mathrm{BOP}$ (+)部位は $1.6 \%$ でった。これについては PCR が 良好に術前から安定していただけでなく，術野におい て歯肉の厚み $(\geqq 2 \mathrm{~mm})$, 角化歯肉幅 $(\geqq 5 \mathrm{~mm})$ と十 分で,さらに上顎の術野においては矯正治療前で歯根 間スペースも $2 \mathrm{~mm}$ 以上あり，歯間乳頭保存術が可能 であり軟組織のマネージメントが行い易く，初期の創 面閉鎖，創傷の安定化が高く維持されていたことに起 因するかもしれない8,10)。本症例においては人工骨と 自家骨を別々の部位に用いているが，特に人工骨がど の程度の骨伝導能を発揮し，新生骨の添加および形成 が起こっているのか判別することは不可能である。さ
らに今回使用した骨補填材は非吸収性であるが，非吸 収性のハイドロキシアパタイトを用いた骨内欠損にお いてアンキローシスと再感染が起きていたとの報 告 ${ }^{11)}$ もあり, 術後感染に対して今後十分に留意する必 要がある。なお歯周組織再生を本質的に評価するため には組織所見が唯一の方法である ${ }^{12)}$ とされているが, 臨床において生検は非常に困難で多くの問題を伴う。 近年, 歯科用 C T を用い歯周組織再生療法後の治癒評 価を行ったとする報告 ${ }^{13,14)}$ があり, 複雑な骨欠損形態 や再生療法後の治癒経過および歯槽骨再生量を非侵襲 的に，かつ客観的に評価・把握できることから今後, 歯周組織再生（特に歯槽骨）の評価において一つの代 替ツールに成り得るかもしれない。

本症例のような歯周病患者における矯正治療はプ ラークコントロールを行い易い口腔内環境の創出はも ちろんのこと, 審美性や咬合機能の改善を同時に図り, 長期的に歯周炎の再発を予防することにある ${ }^{15-17)}$ 特に本患者は PTM が多数認められただけでなく，骨 格性下顎前突症であったため歯科矯正学的観点からは 全顎的な矯正治療が理想的であり, 外科的矯正治療の 適応であった。当初から歯周治療における矯正治療の 役割と目的について患者の理解は得られていたが, 顔 貌のプロファイルまで含めた大幅な審美性の改善や外 科的矯正治療までは希望しないとのことから非外科的 部分矯正治療にて対応することとした。しかし重度歯 周炎罹患患者においては, 矯正的歯の移動を行うこと により一時的に咬合関係が変化しわずかな咬合力の増 加が二次性咬合性外傷を引き起こすリスクがある18)。 また, 歯周疾患を伴う成人矯正の場合, 歯槽骨吸収と 共に歯冠・歯根長比が悪化するため, 力学的抵抗中心 が根尖側に移動しているためより厳密なトルクコント ロールが必要となる15)。さらに本症例では歯槽骨レ ベルが低い上に歯根長も短いという解剖学的制限も あった。こうしたことから歯周外科後の歯槽骨の回復 を障害しないように, 残存歯への負担を極力減じる必 要があると考えられた。以上のことから，上頡では被 蓋の改善にあたり可撤式のバイトプレートを用いて咬 合を挙上し, 矯正治療中の咬頭干渉, 外傷力 (特に被蓋 逆転時)を最小限にするように努めた。幸い患者は非 常に協力的であったばかりでなく，日中のバイトプ レートの装着（6～8 時間/日）にあまり抵抗なく顎関 節症状も生じなかったことから早期に切端咬合位まで 咬合挙上が可能であった。これにより外傷性咬合を可 能な限り回避し動的治療期間が短縮（被蓋改善に 4 力 月）されたと考えられる。下顎については残存歯や歯 周組織への負担を最小限にし, さらに動的治療期間の 短縮化を期待し，埋入および除去も容易な矯正用アン 
カースクリュー19,20) を絶対的固定源として利用した。 なお, 矯正治療中は月に最低 1 度は来院して頂きプ ラークコントロールや動的治療期間中に生ずる歯の早 期接触, 咬頭干渉等を確認し, 適宜咬合調整を行った。 上下顎前歯部に若干の歯根吸収を認めたが, 全て失活 することなく動的矯正治療を終了した。本患者におい ては歯周外科後の再評価において $\mathrm{PD} \geqq 4 \mathrm{~mm}$ の部位 は $0.8 \%$ で歯槽骨レベルも概ね安定し, PCR も良好で あったため歯周外科後 6 力月で矯正治療に入ったが, 客観的に歯周外科後の矯正治療開始のタイミングを見 極めるため細菌検査を積極的に導入し, 細菌の有無や 細菌叢の変化を評価したり ${ }^{21)}$, 歯周外科処置後の骨欠 損の状態を歯科用 C T を用いて評価した上で矯正治療 の開始時期を決定することが望ましいと考えられる。 本症例のように PTM と骨内欠損を多く有する患者に おける包括的治療の予知性を高め最適化するために は, 外科処置 (切除療法, 再生療法, 使用するマテリ アルの特性, 骨欠損の形態), 矯正治療 (歯の移動方向 , 移動様式, トルクコントロール等）において各々の 内容を十分吟味し，それらの関わりを検証できるエビ デンスがまだまだ必要であると考えられる。

本症例においては初診時 12,22 と 33,43 に特に, 強く早期接触が認められ，側方のガイドも同部のみで あり，臼歯部では歯列不正が著しい $17 ， 47$ と 26, 27, 37 で咬頭干渉があり下顎運動が制限されていた。ま た下顎前突のため適切なアンテリアガイダンスが消失 していた。しかし, 矯正治療および修復治療の結果, 歯列不正の解消と空隙が閉鎖され全顎的に咬合の緊密 化が図られたことで, 最終的に臼歯部でのバーティカ ルストップをより強固に安定化することができた。ま た，側方運動においては犬歯を含んだグループファン クションドオクルージョンへと咬合様式が誘導され, 下顎前歯部の歯軸傾斜が理想的でないものの, 前方滑 走時のアンテリアガイダンスを獲得でき，臼歯部の咬 合負担が大幅に軽減され力のコントロールが良好に図 られていると考えられる。

今回，多くの PTM と骨格性下顎前突症を有する重 度慢性歯周炎患者に対し，歯周基本治療，歯周外科， 非外科的部分矯正治療および口腔機能回復治療といっ た包括的アプローチを試みた結果，低侵襲かつ効率的 に歯周組織の環境改善および歯列の連続性，臼歯部咬 合支持の回復, 適切なアンテリアガイダンスが獲得さ れた。これらにより炎症および力のコントロールが達 成され, 現在も良好に歯周組織と咬合の安定が維持さ れていると考えられる。

本論文の要旨は, 第 56 回秋季日本歯周病学会学術大会
（2013 年 9 月 22 日前橋）において発表し, 最優秀臨床ポス ター賞を受賞した。本報告は同発表内容に一部追加, 改変 して掲載した。なお, 本症例の学会発表および学会誌掲載 に際し, 患者に全ての報告内容と画像, 臨床データの使用 を説明し，口頭および文書による同意を取得した。

\section{文献}

1) Towfighi PP, Brunsvold MA, Storey AT, Arnold RM, Willman DE, McMahan CA : Pathologic migration of anterior teeth in patients with moderate to severe periodontitis. J Periodontol, 68: 967-972, 1997

2) Martinez-Canut P, Carrasquer A, Magán R, Lorca A : A study on factors associated with pathologic tooth migration. J Clin Periodontol, 24 : 492-497, 1997

3) Brunsvold MA : Pathologic tooth migration. J Periodontol, $76:$ 859-866, 2005

4) Carranza FA: Periodontal response to external forces. Newman MG, Takei HH, Klokkevold PR, Carranza FA Jr, Carranza's Clinical Periodontology 11th ed. Elsevier Saunders, St. Louis, 151-159, 2012

5) Lang NP, Tonetti MS : Periodontal risk assessment (PRA) for patients in supportive periodontal therapy (SPT). Oral Health Prev Dent. 1:7-16, 2003

6) Rosling B, Nyman S, Lindhe $J$ : The effect of systemic plaque control on bone regeneration in infrabony pockets. J Periodontol, 3 : 38-53, 1976

7) Papantonopoulos GH : Smoking influences decision making in periodontal therapy: a retrospective clinical study. J Periodontol, 70 : 1166-1173, 1999

8) Cortellini $\mathrm{P}$, Tonetti MS : Clinical performance of a regenerative strategy for intrabony defects : scientific evidence and clinical experience. J Periodontal, 76 : 341-350, 2005

9) Kim E, Fallahrastegar A, Hur YY, Jung IY, Kim S, Lee SJ : Difference in root canal length between Asians and Caucasians. Int Endod J, 38 : 149-151, 2005

10) Cortellini P, Prato GP, Tonetti MS. The simplified papilla preservation flap. A novel surgical approach for the management of soft tissues in regenerative procedures. Int J Periodontics Restorative Dent, 589-599, 1999

11) Yoshinuma N, Sato S, Fukuyama T, Murai M, Ito $\mathrm{K}$ : Ankylosis of nonresorbable hydroxyapatite graft material as a contributing factor in recurrent periodontitis. Int J Periodontics Restorative Dent, 
$32:$ 331-336, 2012

12) Garrett S. Periodontal regeneration around natural teeth. Ann Periodontol, 1 : 621-666, 1996

13) Ito K, Yoshimura N, Goke E, AraiY, Shinoda K : Clinical application of a new compact computed tomography system for evaluating the outcome of regenerative therapy a case report. J Periodontal, $72:$ 696-702, 2001

14）小野智弘, 濱地貴文, 前田勝正：垂直性骨欠損を有 する広汎型重度慢性歯周炎患者に対して EMDOGAIN $^{\circledR}$ を使用した歯周組織再生療法を行い, 歯科用 CTを用い三次元的に解析を行った一症例 . 日歯周誌, 55 : 141-153, 2011.

15) Gkantidis N, Christou P, Topouzelis N : The orthodontic-periodontic interrelationship in integrated treatment challenges : a systematic review. J Oral Rehabil, 37 : 377-390, 2010

16) Maeda S, Maeda Y, Ono Y, Nakamura K, Sasaki T : Interdisciplinary treatment of a patient with severepathologic tooth migration caused by localized aggressive periodontitis. Am J OrthodDentofacialOrthop, $127: 374-384,2005$
17) Nakamura Y, Gomi K, Oikawa T, Tokiwa H, Sekiya $\mathrm{T}$ : Reconstruction of a collapsed dental arch in a patient with severe periodontitis. Am J OrthodDentofacialOrthop, 143 : 704-712, 2013

18）佐分利清信:歯周矯正を臨床に活用するための考察. 日本臨床歯周病学会誌 , 28：24-32, 2010

19) Kasaj A, Wehrbein H, Gortan-Kasaj A, Reichert C, Willershausen B. Interdisciplinary approach for the treatment of periodontally compromised malpositioned anterior teeth : a case report. Cases J2 : e8568, doi : 10. 4076/1757-1626-2-8568, 2009.

20) Agarwal S, Gupta S, Chugh VK, Jain E, Valiathan A, Nanda R. Interdisciplinary treatment of a periodontally compromised adult patient with multiple missing posterior teeth. Am J OrthodDentofacialOrthop, $145:$ 238-248, 2014

21）富川和哉, 河野隆幸, 山本直史, 岩本義博, 下江正 幸, 山口知子, 本郷昌一, 宮本 学, 前田博史, 高 柴正悟：細菌感染度を評価しながら包括的歯周治療 を行った広沉型侵襲性歯周炎患者の一症例, 日歯周 誌, $55 ： 340-348,2013$. 